Research Article

Journal of Extension Education

Vol. 30 No. 4, 2018

DOI:https://doi.org/10.26725/JEE.2018.4.30.6173-6176

\title{
Involvement of Farm Women Groups in the Planning, Production and Marketing Aspects of Vegetables in Kerala
}

\author{
Revathy Chandran ${ }^{1}$ and G. S. Sreedaya ${ }^{2}$
}

\begin{abstract}
Kerala is a consumer state as far as vegetables are concerned. Major share of the fresh vegetable supply for the state comes from neighbouring states. Promoting vegetable cultivation in the state coupled with suitable marketing mechanism will not only help to make the state self reliant in vegetable production but also ensure year round availability of quality vegetables. The study was conducted in six panchayats of Kollam district in Kerala which includes the selected women groups of Kudumbashree, Vegetable and Fruit Promotion Council Keralam (VFPCK) and Agricultural Technology management Agency (ATMA). There were two categories of respondents viz, members of farm women groups and the extension facilitators. According to the study, majority of the women farmers showed medium level of involvement in the planning, production and marketing aspects of vegetables. It can be inferred that the variable increase in income showed a positive and significant relationship with planning, production and marketing aspects of vegetables. Achievement motivation also showed a significant positive relationship with production.
\end{abstract}

Keywords : Farm women, Production; Marketing; Vegetables; Planning; Kerala

\section{INTRODUCTION}

There are so many constraints which restrict the production of vegetables. The most important constraint is the average size of land holding which is subjected to fragmentation. The recommended intake. India is the largest producer of many fresh fruits and vegetables (FAO, 2010). India is the second largest producer of vegetables with an annual production of 87.53 million tonnes from 5.86 million hectare having a share of $14.4 \%$ of the world population. In India, fruits and vegetables occupy nearly 4.24 percent of area (Haque, 2003). Until recently Kerala was a consumer state, when the total requirement is 27 lakh tonnes the state could produce only 6 lakh tonnes (Anonymous, 2015).

\section{METHODOLOGY}

The study was conducted in six panchayats of Kollam district of Kerala which includes the selected women groups of Kudumbashree, Vegetable and Fruit Promotion Council Keralam (VFPCK) and Agricultural Technology Management Agency (ATMA). There were two categories of respondents viz., members of farm women groups and the extension

1. PG. Scholar (Agricultural Extension) and 2. Assistant professor, Department of Agricultural Extension, College of Agriculture, Vellayani, Thiruvananthapuram, Kerala.

Received : 15-03-2018; Accepted : 26-04-2018 
facilitators. Six panchayats were identified from the district based on the number of maximum farm women groups i.e, purposeful sampling and one group was selected from each panchayat by random sampling, Thus six groups were selected and 15 members were selected randomly from each of the selected six groups. Thirty extension functionaries from Kollam district were selected randomly. Thus a total of 120 respondents was the sample size for this study. The data was collected using pre tested interview schedule, PRA (Participatory Rural Appraisal) and Focus group discussions.

\section{FINDINGS AND DISCUSSION}

The findings of the study are given in this section.

Table 1

Distribution of Respondents based on their Involvement

$(n=90)$

\begin{tabular}{|c|c|c|c|c|}
\hline $\begin{array}{c}\text { SI. } \\
\text { No }\end{array}$ & Category & $\begin{array}{c}\text { Score } \\
\text { range }\end{array}$ & $\begin{array}{c}\text { Freq } \\
\text { uency }\end{array}$ & $\begin{array}{c}\text { Percen } \\
\text { tage }\end{array}$ \\
\hline
\end{tabular}

Distribution of Respondents based on their Involvement in Planning

\begin{tabular}{|l|l|l|l|l|}
\hline 1 & Low & $<96$ & 21 & 23 \\
\hline 2 & Medium & $96-105$ & 52 & 58 \\
\hline 3 & High & $>105$ & 17 & 19 \\
\hline
\end{tabular}

Distribution of Respondents based on their Involvement in Production of Vegetables

\begin{tabular}{|l|l|l|l|l|}
\hline 1 & Low & $<37$ & 18 & 20 \\
\hline 2 & Medium & $37-44$ & 50 & 56 \\
\hline 3 & High & $>44$ & 22 & 24 \\
\hline
\end{tabular}

\begin{tabular}{|l|l|l|l|l|}
\hline $\begin{array}{c}\text { SI. } \\
\text { No }\end{array}$ & Category & $\begin{array}{c}\text { Score } \\
\text { range }\end{array}$ & \multicolumn{1}{|c|}{$\begin{array}{c}\text { Freq } \\
\text { uency }\end{array}$} & $\begin{array}{c}\text { Percen } \\
\text { tage }\end{array}$ \\
\hline \multicolumn{5}{|c|}{$\begin{array}{l}\text { Distribution of Respondents based on their } \\
\text { Involvement in Marketing Aspects of } \\
\text { Vegetables }\end{array}$} \\
\hline 1 & Low & $<19$ & 16 & 18 \\
\hline 2 & Medium & $19-24$ & 52 & 58 \\
\hline 3 & High & $>24$ & 22 & 24 \\
\hline
\end{tabular}

A perusal of Table 1 showed that majority of the women farmers (58\%) showed medium level of involvement in the planning and 23 per cent of the farm women exhibited low involvement in planning, whereas only 19 percent of the farm women showed high level of involvement in the planning.

According to Table 1, 56 per cent of the farm women had medium involvement in production aspects of vegetables. Only $24 \%$ of the farm women showed higher involvement and 20 percent of the farm women showed low involvement. Majority of the respondents (58\%) showed medium involvement in the marketing aspects of vegetables. On the contrary, 24 per cent showed high involvement in marketing and an $18 \%$ showed low involvement in the marketing of vegetables.

From Table 2, it can be inferred that the variable increase in income showed a positive and significant relationship with planning (0.236), production (0.446) and marketing aspects of vegetables (0.301). Achievement motivation also showed a significant positive 
Involvement of Farm Women Groups in the Planning, Production and Marketing Aspects of Vegetables in Kerala

Table 2

Correlation of Planning, Production and Marketing aspects of Vegetables with Independent Variables

$(n=90)$

\begin{tabular}{|c|l|c|c|c|}
\hline SI. No & \multicolumn{1}{|c|}{ Independent variables } & Planning & Production & Marketing \\
\hline 1 & Age & -0.005 & 0.073 & 0.203 \\
\hline 2 & Education & 0.155 & 0.173 & 0.122 \\
\hline 3 & Annual income & -0.037 & -0.019 & -0.052 \\
\hline 4 & Increase in income & $0.236^{*}$ & $0.446^{*}$ & $0.301^{*}$ \\
\hline 5 & Area under vegetable cultivation & -0.091 & 0.198 & -0.043 \\
\hline 6 & Social participation & -0.108 & 0.133 & -0.089 \\
\hline 7 & Achievement motivation & 0.015 & $0.212^{*}$ & -0.050 \\
\hline 8 & Economic motivation & 0.002 & -0.035 & 0.083 \\
\hline
\end{tabular}

*-Significant at 5\% level.

relationship with production (0.212). Rest of the variables possessed a non significant relationship with planning, production and marketing aspects of vegetables. Increase in income motivates the farmers to have a systematic and scientific approach towards farming. An increase in income would make the farm women realize the importance of planning and knowing the market for the production of vegetables. So this may be the reason for the positive and significant relationship between increase in income and planning, production and marketing aspects of vegetables. The urge to achieve something is a motivating factor that raises the energy of the group members and hence it helps in enhancing the productivity. The people with achievement motivation have a high positive energy which helps to overcome the different barriers in production and thereby improves the productivity.

\section{CONCLUSION}

The study in planning, production and marketing aspects of vegetable cultivation revealed that majority of the respondents had medium involvement in planning, production and marketing aspects of vegetable cultivation. From the correlation analysis it was found that the variable increase in income showed a significant positive relationship with planning, production and marketing aspects of vegetables. Achievement motivation showed a positive significant relationship with the production aspect. Since an increase in income showed a positive relationship with planning, production \& marketing aspects of vegetables, the extension agents need to focus on 'income generation' while formulation extension strategies for such women groups.

\section{REFERENCES}

Anonymous. (2015). Reduction in vegetable 
flow to Trivandrum from Tamil Nadu. Mathrubhumi, 3 June.2015,p.4.

FAO. (2010). The state of food and agriculture. Food and Agriculture Organisations of United States, Rome.
Haque, T. (2003). Decent Work in Agriculture in India In. A Report of the Asian Regional Workshop 18th to 21st August 2003, International Labour Office, Bangkok. 